http://dx.doi.org/10.11646/phytotaxa.117.2.3

\title{
Euphorbia otjipembana subsp. okakoraensis (Euphorbiaceae), a new subspecies from the Kaokoveld, Namibia, with an amplified description of Euphorbia otjipembana
}

\author{
WESSEL SWANEPOEL* \\ *H.G.W.J. Schweickerdt Herbarium, Department of Plant Science, University of Pretoria, Pretoria 0002, South Africa. \\ Postal address: P.O. Box 21168, Windhoek, Namibia. E-mail: wessel@kaokosafari.com
}

\begin{abstract}
Euphorbia otjipembana was hitherto only known from the type locality within the Kaokoveld Centre of Endemism, northwestern Namibia. Subsequently several additional populations were discovered, allowing for an amplified description of the species and the recognition of two subspecies. Euphorbia otjipembana subsp. okakoraensis, here described as a new subspecies, is only known from a small area within the Kaokoveld Centre. Diagnostic characters for subsp. okakoraensis include a shrubby habit and medium (up to $1 \mathrm{~m}$ ) height, 5-7-angled, scarcely constricted branches with two pairs of spines per node and single cymes comprising of three horizontally arranged cyathia. A key as well as a comparative table with diagnostic morphological characters to distinguish between the two subspecies of E. otjipembana is provided.
\end{abstract}

\section{Introduction}

At present three described species of medium-sized (up to $1 \mathrm{~m}$ tall), shrubby succulent Euphorbia Linnaeus (1753: 450), belonging to subgenus Euphorbia section Euphorbia, are known from the Namibian part of the Kaokoveld (Leach 1976, Bruyns 2006). Euphorbia kaokoensis (White, Dyer \& Sloane 1941: 965) Leach (1976: 33) occurs from the eastern Kaokoveld (Kamanjab area) to the northern and northwestern parts (Etengwa and Onjuva respectively). Euphorbia subsalsa subsp. fluvialis Leach (1976: 29) is widespread in the Kunene River Valley, from the Ruacana Falls to Epupa. Euphorbia otjipembana Leach (1976: 29) was hitherto only known from the type locality near Otjipemba in the northern Kaokoveld (Leach 1976, Craven 1999, Germishuizen \& Meyer 2003). In this contribution a new subspecies of E. otjipembana is described and an amplified description of the species is provided.

During a botanical expedition to the Otjihipa Mountains in the far northwestern corner of Namibia in April 2006, the author encountered an unusual, succulent Euphorbia at the foot of the Okakora Mountains, 9 $\mathrm{km}$ to the northwest of Otjipemba, the type locality of E. otjipembana. During subsequent expeditions to the same general area, additional populations of E. otjipembana were found in the Otjihipa and Omavanda Mountains, which are situated to the west and east of Otjipemba respectively. While the Otjihipa and Omavanda plants could at once be recognized as belonging to E. otjipembana, this was not the case with the Okakora plants which had, inter alia, taller branches with a different colour. Close examination, however, revealed many similarities with E. otjipembana. The Okakora plants are here proposed as representing a distinct new subspecies of E. otjipembana. A study of the Euphorbia holdings in PRE and WIND revealed only one other collection of the new subspecies (Leistner, Oliver, Steenkamp \& Vorster 155) in PRE, filed under E. otjipembana.

Live material of the new species was studied in the field. Morphological characters in the following descriptions were all determined from live specimens and from fresh flowering material and ripe fruit. 


\section{Taxonomic treatment}

Euphorbia otjipembana Leach (1976: 29)

Type:-NAMIBIA. Kunene Region: Stony eastern slopes of Baynes Mountains, north of Otjipemba, 1712BB, 21 July 1973, Leach \& Cannell 15044 (holotype PRE!, isotypes BM, K, LISC, M, MO, SRG, WIND!).

Succulent, spiny shrub with fresh green or grey-green epidermis, up to $1 \mathrm{~m}$ tall, diam. up to $2 \mathrm{~m}$. Trunk single, nude for 30-200 mm or multi-stemmed from ground level. Bark on trunk grey, on branches and central stem fresh green or grey-green, grey towards base. Branches numerous, ascending, occasionally slightly spirally twisted, $0.15-0.8 \mathrm{~m}$ long, 18-35 mm diam., constricted at base, slightly or not constricted into segments, 20$60 \mathrm{~mm}$ long, 4-7-angled, 3-5-angled on branchlets, angles compressed, sometimes wing-like, margins even, slightly sinuate, serrate or crenate-serrate, with horny spine shields and spines; secondary branches on apical two thirds of branches. Spine shields decurrent, \pm rectangular between lower and upper spine pairs, abruptly narrowing below lower pair, narrowly cuneate or \pm parallel-sided towards base, or cuneate from apex towards base, separate initially, eventually forming a subcontinuous or continuous horny margin, 2.0-5.2 mm wide, 5$15 \mathrm{~mm}$ long (when separate); spines paired, lower pair diverging, \pm horizontally spreading, $4-15 \mathrm{~mm}$ long, \pm regularly arranged, 5-14 $\mathrm{mm}$ apart along angles; upper pair shorter, 0.8-7 $\mathrm{mm}$ long, from very widely divergent to parallel and perpendicular to spine-shield, straight or down-curved, often projecting $\pm 45^{\circ}$ upwards, one or more short (up to $5 \mathrm{~mm}$ long) or rudimentary spines sometimes present towards base of spine shield. Leaves deciduous, sessile, green, cherry-green or yellow-pink, semi-circular, ovate to broadly trullate or pentagonal, apex often apiculate, margin entire or irregularly dentate, thick, stiff, curved towards abaxial side, $0.8-1.6 \times 0.6-1.6 \mathrm{~mm}$; scar elliptic, triangular or oblong-elliptic. Inflorescences cymose, occasionally compound, yellow, cherry-red, greenish red or reddish yellow, glabrous, with single, shortly pedunculate cymes, each comprising three horizontally arranged cyathia; peduncle bibracteate, up to $3.0 \mathrm{~mm}$ long; bracts semi-circular, obovate or rectangular, margin irregularly denticulate, crenulate or fimbriate-denticulate, not thickened or thickened towards base, caducous and leaving prominent scar, 1.0-2.5 × 1.4-2.5 mm; central initial cyathium male and marcescent, bisexual laterals borne on bibracteate cyme branches up to $3 \mathrm{~mm}$ long; bracts obovate, \pm rectangular or triangular, not thickened or thickened towards base, caducous and leaving prominent scar, 1.4-2.0 $\times 1.1-1.8 \mathrm{~mm}$, margin irregularly denticulate. Involucre obconic, in male cyathium laterally compressed by laterals, $2.3-2.7 \mathrm{~mm}$ long, 2.4-3.2 $\mathrm{mm}$ diam. including glands, in bisexual cyathia 1.4-3.6 mm long, 2.8-4.0 mm diam. including glands; glands 5(-6), slightly fleshy or fleshy, erect, sub-erect or spreading, separate or contiguous, suborbicular, transversely \pm oblong, oblong-elliptic or elliptic, $0.7-2.1 \times$ $0.5-0.8 \mathrm{~mm}$, smaller in male cyathium than in bisexual, concave adaxially, convex abaxially, yellow, yellowish pink or yellowish red, upper surface rugulose, margin broad in male cyathium, narrower in bisexual cyathia, \pm entire, irregularly crenate or crenulate; lobes $5(-6)$, glabrous, sub-quadrate, suborbicular or \pm obovate, prominent to obscurely vertically ridged abaxially, margin at apex irregularly fimbriate, often 2-4lobed, $1.0-1.5 \times 1.0-1.5 \mathrm{~mm}$. Male flowers arranged in 5(-6) fascicles of 2(-3) flowers each opposite lobes, well exerted from involucre, subtended by filiform-laciniate bracteoles $\pm 1.3 \mathrm{~mm}$ long; each fascicle subtended and loosely enwrapped by a broad fimbriate-laciniate often 2-4-lobed bract, 2.0-2.8 mm long, 2.2$3.0 \mathrm{~mm}$ wide at apex; pedicels filiform, pale green, when fully developed $\pm 3.1 \mathrm{~mm}$ long in male cyathium, \pm $2.2 \mathrm{~mm}$ long in bisexual cyathia; filaments terete, maroon or green, 1-1.7 mm long; anther thecae orbicular, flattened, orange-red or pale brown, $0.8 \mathrm{~mm}$ diam., pollen bright yellow. Female flowers erect, glabrous; ovary elliptic or oblong-elliptic, trigonous, occasionally 4-angled, green, 0.9-1.0 mm long, 1.0-1.3 mm diam., included in involucre, subsessile on short, triangular, quadrate or pentagonal pedicel, $\pm 0.5 \times 0.9 \mathrm{~mm}$ diam. Ovule \pm elliptic, $\pm 0.6 \times 3.0 \mathrm{~mm}$ diam., suspended under triangular or oblong $\pm 0.3 \mathrm{~mm}$ long obturator, margin irregularly denticulate-fimbriate; female flower rudimentary in male cyathium; styles 3(-4), ascending spreading, 1.7-2.6 mm long, united into stout column for $0.3-0.7 \mathrm{~mm}$, apex shortly bifid, stigmas rugulose granulose. Capsule 3(-4)-locular, deeply lobed, elliptic or ovate, apex emarginate, truncate or obtuse, greenish red or greenish yellow, with pale dots, 3.0-3.8 $\times 3.2-4.3 \mathrm{~mm}$, held erect, exerted from involucre but base 
within, on a stout pedicel, green, $\pm 2.5 \mathrm{~mm}$ long, $\pm 2.3 \mathrm{~mm}$ diam.; perianth reduced to a pentagonal obconic rim below the capsule, whitish, $\pm 1.3 \mathrm{~mm}$ high, $2.3-2.8 \mathrm{~mm}$ diam. Seed narrowly ellipsoid, ovoid, obovoid, oblongoid or subglobose, verrucose-rugulose, pale brown, suture dark brown, 1.7-2.5 ×1.0-1.4 × 1.2-1.5 mm.

\section{Key to the subspecies of $E$. otjipembana (for more differences see Table 1)}

1. Branches usually fresh (bright) green, rarely grey-green; spine shields $2.8-5.2 \mathrm{~mm}$ wide at apex, $1.5-2.6$ times as long as broad; bracts on peduncle and cyme branches leaving prominent scars..... subsp. otjipembana

- Branches grey-green; spine shields 2-3 mm wide at apex, 2.7-4.4 times as long as broad; bracts on peduncle and cyme branches not leaving prominent scars subsp. okakoraensis

Euphorbia otjipembana Leach subsp. okakoraensis Swanepoel, subsp. nov. (Figs. 1 \& 2)

Differs from the typical subspecies in the branches being consistently grey-green; spine shields more slender, 2.7-4.4 times as long as broad (at apex), usually rectangular between upper and lower spine pairs; peduncular and cyme branch bracts not leaving prominent scars; cyathia occasionally with six glands and six involucral lobes; glands erect, slightly fleshy; male flowers occasionally arranged in six fascicles; female flowers occasionally with ovary 4lobed and four styles; capsule occasionally 4-locular.

Type:-NAMIBIA. Kunene Region: Stony northeastern slopes of Okakora Mountains near Okombambi, 1712BB, 930 m, 24 March 2007, Swanepoel 271 (holotype WIND!; isotype PRE!).

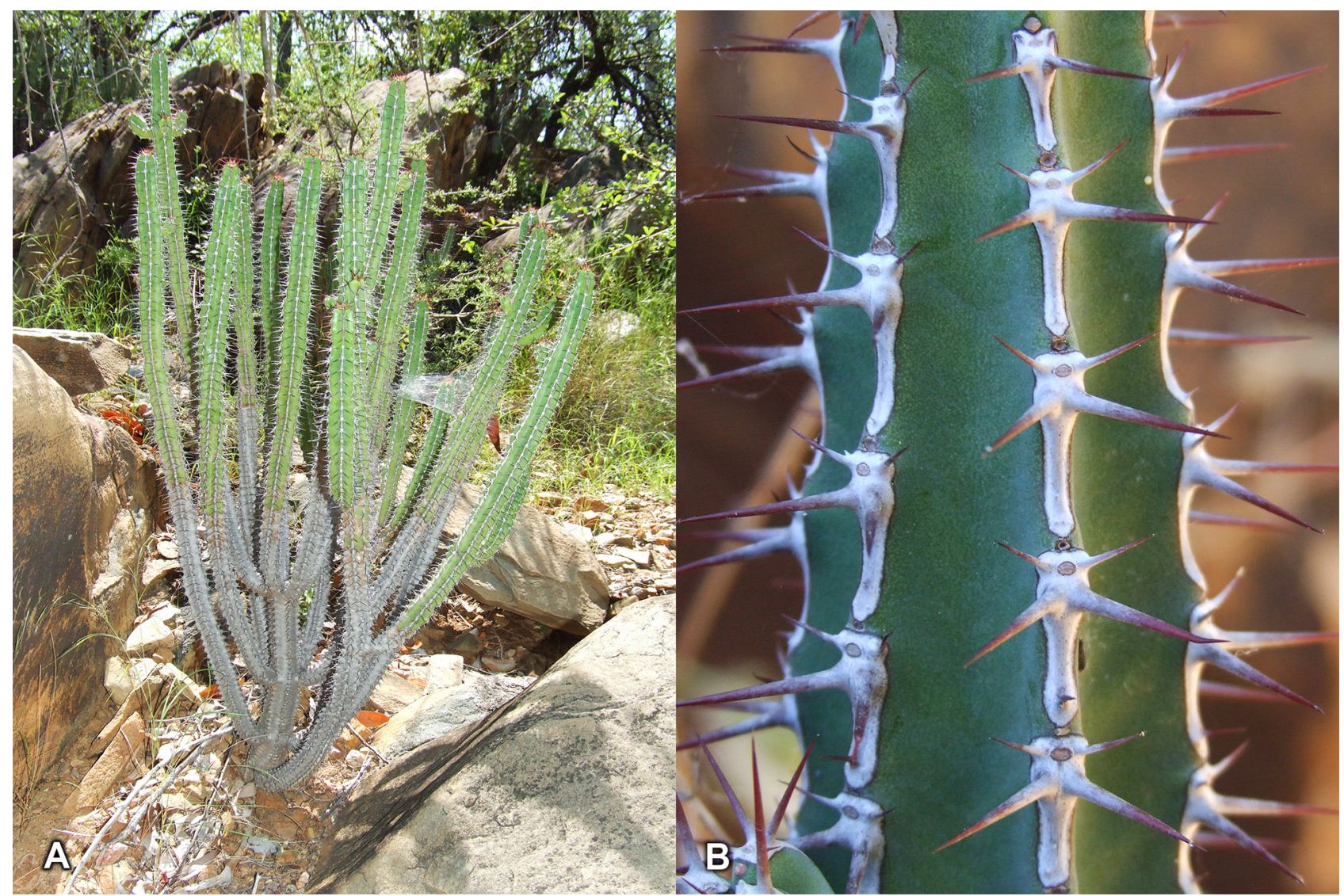

FIGURE 1. Euphorbia otjipembana subsp. okakoraensis: (A) plant in natural habitat, $\pm 0.8 \mathrm{~m}$ tall; (B) branch indicating spine shields.

Phenology:-Cyathia were recorded on subsp. okakoraensis from August to October.

Distribution and habitat:-At present Euphorbia otjipembana subsp. okakoraensis is known only from the type locality, in the northern part of the Kaokoveld, northwestern Namibia (Fig. 3). This locally falls within the Kaokoveld Centre of Endemism, a biogeographical region extending from northwestern Namibia to southwestern Angola (Van Wyk \& Smith 2001). It occurs $112 \mathrm{~km}$ from the coast, near Okombambi, in a narrow gorge between the Baynes Mountains to the east and the Okakora Mountains to the west at an elevation of $930 \mathrm{~m}$. Average annual rainfall in the area is $\pm 200 \mathrm{~mm}$ (Mendelsohn et al. 2002). The subspecies 
is locally uncommon and grows in rock crevices on the northeast-facing aspect of the Okakora Mountains in full sun and in partially shaded areas. The substrate is stony soil derived from greywacke of the Mulden Group of the Damara Sequence (Schreiber et al. 2002).

Conservation status:-Although rare and known from a single locality only, subsp. okakoaraensis is probably not threatened as it occurs in a remote, almost inaccessible area. The local Ovahimba do not distinguish among E. otjipembana subsp. okakoraensis, E. otjipembana subsp. otjipembana, E. kaokoensis and E. subsalsa subsp. fluvialis and use the vernacular Otjiherero name 'ohahi' for all four taxa. The subspecies okakoraensis is thus regarded as being poisonous and probably without any use, other than for poison. No signs of damage caused by animals or humans could be found on any of the in-situ specimens examined.
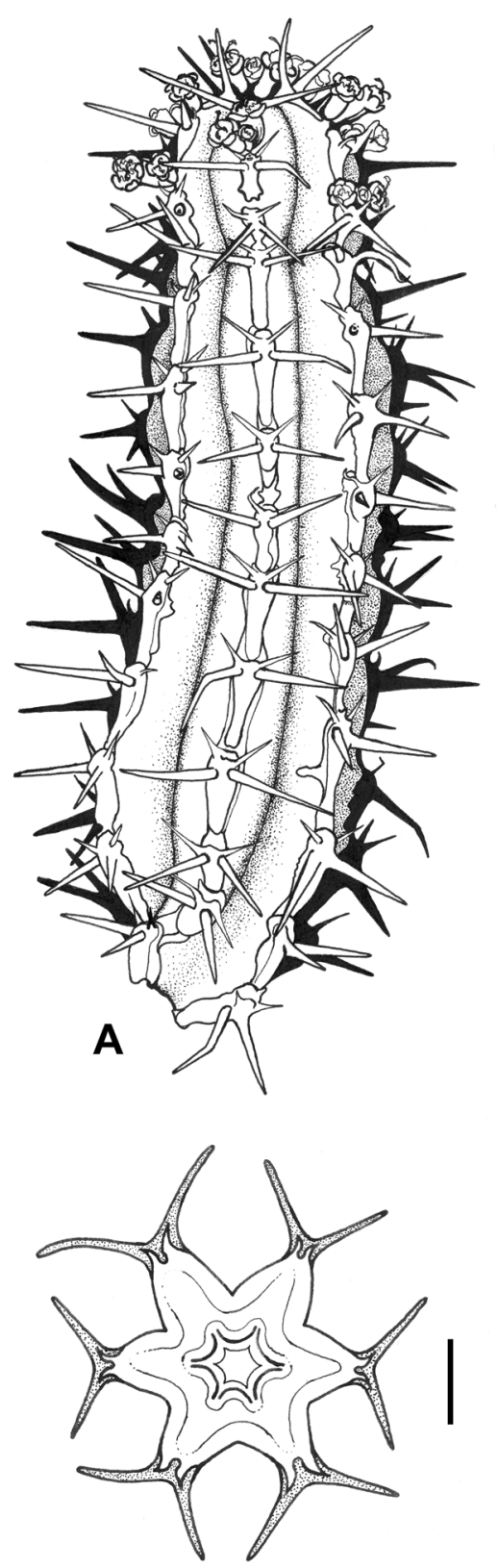

B

LD
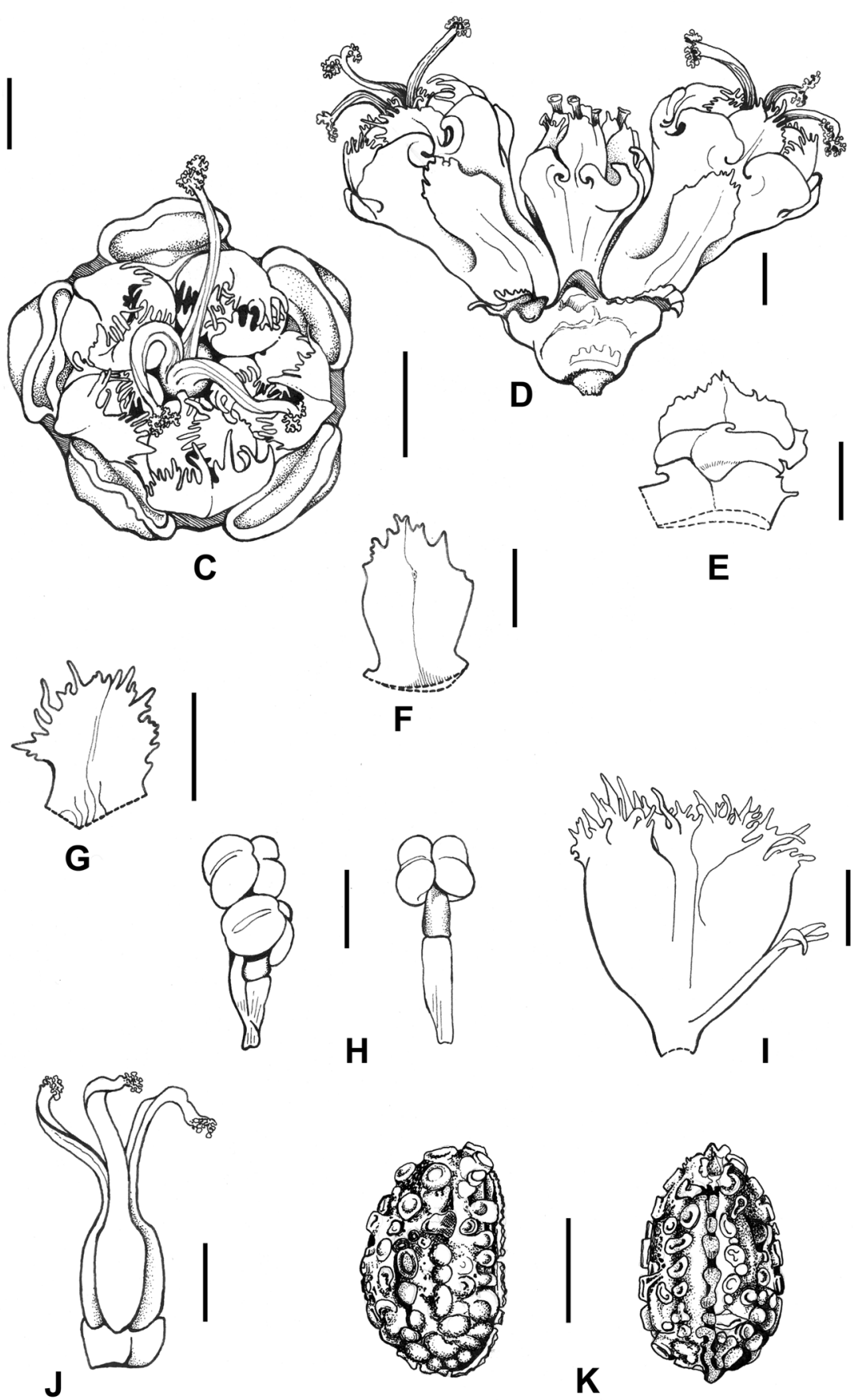

E

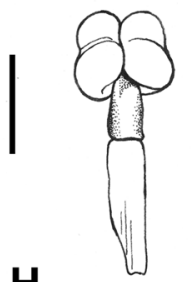

H
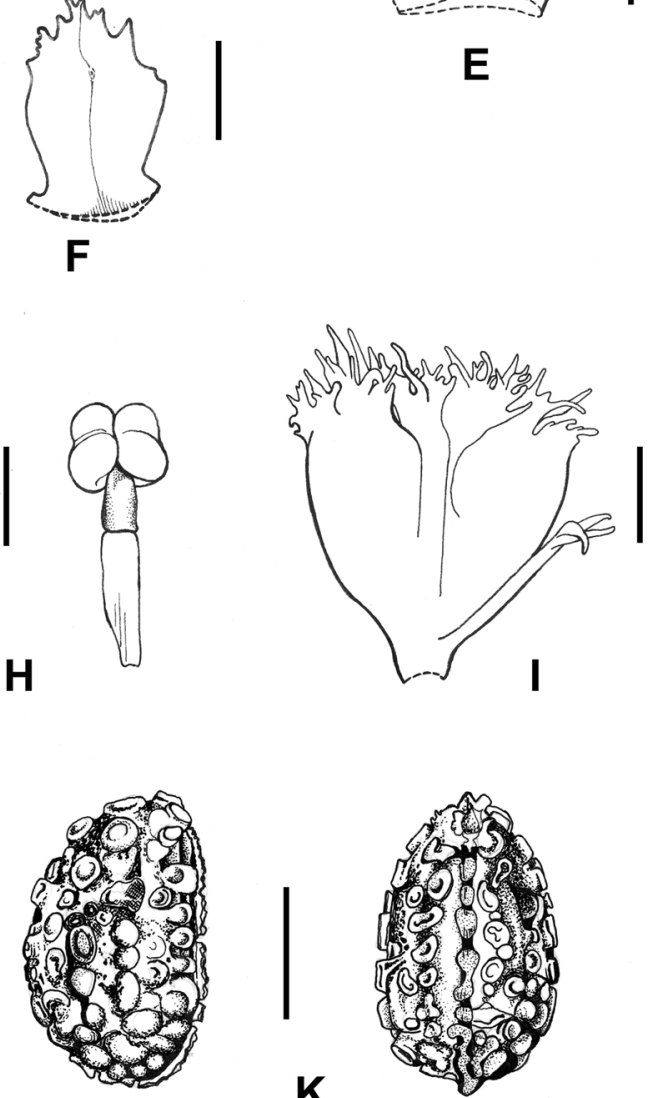

$\mathbf{K}$

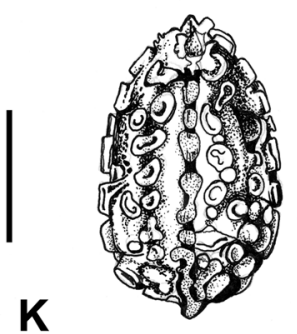

FIGURE 2. E. otjipembana subsp. okakoraensis: (A) flowering branch; (B) branch in transverse section; (C) bisexual cyathium from above; (D) cyme with old central male cyathium and two bisexual cyathia; (E) peduncular bract; (F) cyme branch bract; (G) involucral lobe (adaxial side); (H) male flowers (rarely fused at base, left); (I) fascicular bract with bracteole; (J) female flower; (K) seed. Scale bar $5 \mathrm{~mm}$ (A and B), or $1 \mathrm{~mm}(\mathrm{C}-\mathrm{K})$. All from Swanepoel 271. Illustration by Lesley Deysel. 
Etymology:-The specific epithet refers to the Okakora Mountains, the Ovahimba name for the mountains where the new subspecies is found.

Additional specimen examined (paratype):-NAMIBIA. Kunene Region: Kaokoveld, Otjomborombonga, main kloof to the south, 1712BB, 14 July 1976, Leistner, Oliver, Steenkamp \& Vorster 155 (PRE!).

Discussion:-The subspecies okakoraensis differs from the typical subspecies in the branches and in some of the floral characters. In subsp. okakoraensis the stem epidermis is grey-green whereas in subsp. otjipembana the epidermis is usually fresh (bright) green, rarely grey-green. Spine shields in subsp. okakoraensis usually are much narrower at the apex (2-3 mm wide) and-while separate-longer (7-15 mm), usually \pm rectangular between the upper and lower spine pairs and \pm parallel-sided or narrowly cuneate towards the base, appearing drawn out. In the typical subspecies the spine shields are 2.8-5.2 mm wide, 5- 9 $\mathrm{mm}$ long and usually narrowly cuneate from apex to base.

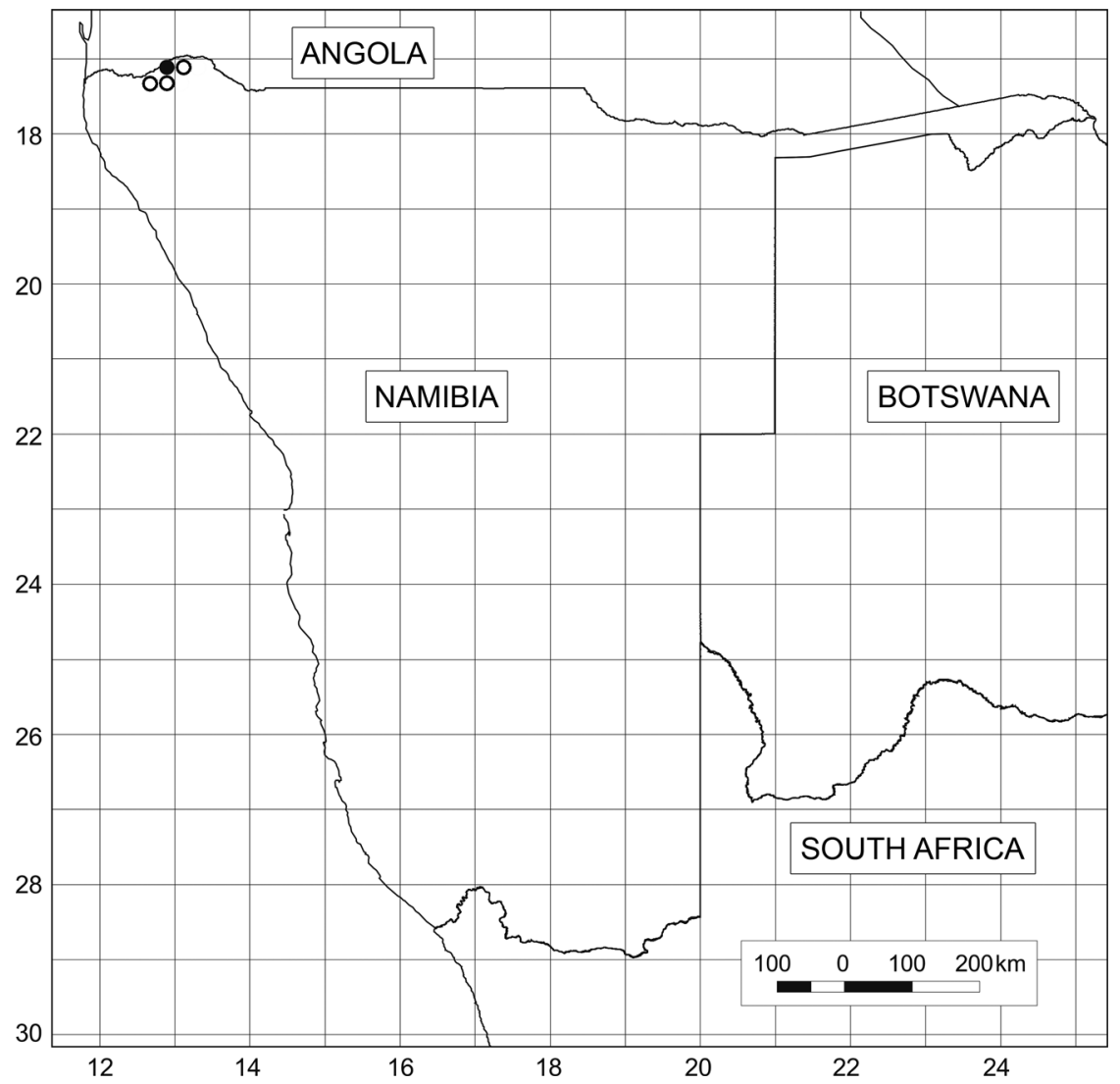

FIGURE 3. Known distribution of E. otjipembana: subsp. otjipembana (open circle), both subspp. okakoraensis and otjipembana (black dot)

Differences in the floral characters include the inflorescences, which in subsp. okakoraensis are shaded in red, yellow and green and the cyathia which occasionally have six glands and six lobes instead of the usual five. In subsp. otjipembana the inflorescences are yellow and the cyathia always have five glands and five lobes. In subsp. okakoraensis the bracts on the peduncle and cyme branches lack thickening towards the base and do not leave prominent scars as in the typical subspecies. The glands in subsp. okakoraensis are always erect and not particularly fleshy, whereas in subsp. otjipembana they are sub-erect or spreading and fleshy. Male flowers in subsp. okakoraensis are arranged in 5 or 6 fascicles whereas in subsp. otjipembana the flowers are arranged in 5 fascicles only. Female flowers in subsp. okakoraensis have the ovary 3- or 4-lobed and the pedicel is triangular, quadrate or pentagonal and the three or four ascending-spreading styles are united in a slightly shorter column than in subsp. otjipembana. In the latter, the ovary is always 3-lobed, the pedicel is pentagonal and the three styles are spreading-recurved. The capsule in subsp. okakoraensis is 3- or 4-locular whereas it is always 3-locular in subsp. otjipembana. 
Apart from the morphological differences, the two subspecies have different flowering times. Subspecies okakoraensis flowers from August to October and subsp. otjipembana from June to August. The different flowering times were maintained even in cultivation in Windhoek, Namibia, where the two subspecies were grown in close proximity during the study. Prominent morphological features to differentiate among subsp. okakoaraensis and the typical subspecies are supplied in Table 1.

TABLE 1. Prominent morphological differences between Euphorbia otjipembana subsp. okakoraensis and subsp. otjipembana

\begin{tabular}{|c|c|c|}
\hline Character & E. otjipembana subsp. okakoraensis & E. otjipembana subsp. otjipembana \\
\hline Habit (height) & up to $1 \mathrm{~m}$ & up to $0.5 \mathrm{~m}$ \\
\hline \multicolumn{3}{|l|}{ Branches } \\
\hline Epidermis (colour) & grey-green & usualy fresh green, rarely grey-green \\
\hline Spine shields & 2.7-4.4 times as long as broad & 1.5-2.6 times as long as broad \\
\hline Length & $7-15 \mathrm{~mm}$ & $5-9 \mathrm{~mm}$ \\
\hline Width at apex & $2-3 \mathrm{~mm}$ & $2.8-5.2 \mathrm{~mm}$ \\
\hline Shape & $\begin{array}{l}\text { usually } \pm \text { rectangular between upper and } \\
\text { lower spine pairs, abrubtly narrowing } \\
\text { below lower pair, narrowly cuneate or } \pm \\
\text { parallel-sided below lower spine pair, } \\
\text { appearing drawn out }\end{array}$ & narrowly cuneate from apex to base \\
\hline Inflorescences & cymose, occasionally compound & cymose \\
\hline Colour & shades of red, yellow and green & yellow \\
\hline Flowering time & August to October & June to August \\
\hline Bracts & not leaving a prominent scar & leaving a prominent scar \\
\hline Glands & 5(-6), erect, slightly fleshy & 5 , sub-erect or spreading, fleshy \\
\hline Involucral lobes & $5(-6)$ & 5 \\
\hline Male flowers & arranged in 5(-6) fascicles & arranged in 5 fascicles \\
\hline \multicolumn{3}{|l|}{ Female flowers } \\
\hline Ovary & 3- or 4-lobed, elliptic & 3-lobed, oblong-elliptic \\
\hline Perianth & triangular, quadrate or pentagonal & pentagonal \\
\hline Styles & 3(-4), ascending-spreading & 3 , spreading-recurved \\
\hline Capsule & $3(-4)$-locular & 3-locular \\
\hline
\end{tabular}

Euphorbia otjipembana subsp. okakoraensis can also be confused with E. kaokoensis and E. subsalsa subsp. fluvialis, which too occur in the mountainous area along the Kunene River in northwestern Namibia. These species share the shrubby habit, the grey-green colour of the branch epidermis and the spine shields with two pairs of spines with subspecies okakoraensis. The latter, however, can be readily distinguished from E. subsalsa subsp. fluvialis by its branches $18-35 \mathrm{~mm}$ in diam., which are 5-7-angled (3-5-angled on branchlets), compressed or wing-like. In E. subsalsa subsp. fluvialis the branches are thinner (10-25 mm) and consistently 4-angled with the angles compressed. The branches in E. kaokoensis are $\pm 20 \mathrm{~mm}$ in diam. and 57-ribbed. The spine shields in E. kaokoensis furthermore differ from the other species in that the four spines are more closely set thus appearing to arise almost from a common point.

\section{Acknowledgements}

I would like to thank Prof. Abraham E. van Wyk, University of Pretoria, for advice and support, Ms Hester Steyn, SANBI, for preparing the distribution map and Ms Lesley Deysel for the line drawings. The curator and staff of the National Herbarium of Namibia are thanked for their assistance during visits to the herbarium. 
The curator, National Herbarium, Pretoria, is thanked for access to their collections; the assistance of Dr. Elizabeth Retief during visits to the herbarium is acknowledged with thanks. I am grateful to the University of Pretoria for financial support. For assistance and companionship during field trips, I am especially grateful to my wife Hannelie and friends Ernst van Jaarsveld, Werner Voigt and Freddie Versfeld.

\section{References}

Bruyns, P.V. (2006) A new subgeneric classification for Euphorbia (Euphorbiaceae) in southern Africa based on ITS and psbA-trnH sequence data. Taxon 55: 397-420. http://dx.doi.org/10.2307/25065587

Craven, P. (ed.) (1999) A checklist of Namibian plant species. Southern African Botanical Diversity Network Report No. 7. SABONET, Windhoek, 204 pp.

Germishuizen, G. \& Meyer, N.L. (eds) (2003) Plants of southern Africa: an annotated checklist. Strelitzia 14: 1-1231.

Leach, L.C. (1976) Euphorbia (Tetracanthae) in Angola and northern Kaokoland. Dinteria 12: 1-35.

Linnaeus, C. (1753) Species Plantarum. Impensis Laurentii Salvii, Stockholm, 1200 pp.

Mendelsohn, J., Jarvis, A., Roberts, C. \& Robertson, T. (2002) Atlas of Namibia. Philip, Cape Town, 200 pp.

Schreiber, U.M., Guj, P., Richards, D.L. \& Kamati, T. (2002) Geological Map of Namibia. Sheet 1712 Swartbooisdrif. Geological Survey of Namibia, Windhoek.

Van Wyk, A.E. \& Smith, G.F. (2001) Regions of floristic endemism in southern Africa: a review with emphasis on succulents. Umdaus Press, Hatfield, Pretoria, 199 pp.

White, A., Dyer, R.A. \& Sloane, B.L. (1941) The succulent Euphorbieae (Southern Africa). Abbey Garden Press, Pasadena, $990 \mathrm{pp}$. 